ONLINE MUTATION REPORT

\title{
Screening of MECP2 coding sequence in patients with phenotypes of decreasing likelihood for Rett syndrome: a cohort of 171 cases
}

\author{
F Kammoun, N de Roux, O Boespflug-Tanguy, L Vallée, R Seng, M Tardieu, P Landrieu
}

J Med Genet 2004;41:e85 (http://www.jmedgenet.com/cgi/content/full/41/6/e85). doi: 10.1136/jmg.2003.014480

$\mathrm{R}$ ett syndrome (RTT) is an X-linked neurodevelopmental disorder that almost exclusively affects females and is generally considered lethal in males during gestation. The typical form is characterised, at anamnesis, by an initial period of stagnation of development followed by regression lasting for several months and occurring between 6 months and 3 years of age. The fully developed clinical picture is dominated by mental retardation, reduction of communication skills, and loss of purposeful hand movements combined with hand stereotypes, progressive microcephaly, abnormal locomotion, and other various minor signs. ${ }^{1}$ The prevalence of RTT has been estimated to be between 0.25 and 1 per 10000 in girls; the figure is probably higher if variant forms are included. ${ }^{2}$ In 1999, it was discovered that a significant proportion of RTT cases are caused by mutations in the MECP2 gene. ${ }^{3}$ However, detection of mutations has been very variable from one series to another, ranging from $19 \%^{3}$ to $100 \%$ positive cases, ${ }^{4}$ presumably due to the profile of the populations studied.

Methyl CpG-binding protein 2 is encoded by a gene containing four exons. Its longest transcript is $10.1 \mathrm{~kb}$ and is mainly expressed in the fetal brain. This 446 residue protein acts as a transcriptional repressor. It includes a methyl binding domain (MBD, residues 78-162), a transcription repression domain (TRD, residues 207-310), a nuclear localisation signal (NLS, residues 255-271), and a 63 residue C-terminal domain (CTD) involved in binding to DNA and in protein stability (reviewed by Nomura $e^{2} \mathrm{al}^{5}$ ).

A number of variant phenotypes in girls was described before the molecular era and included: a form with congenital onset, ${ }^{56}$ a form with early infantile onset dominated by seizures, ${ }^{7}$ a form fruste, ${ }^{8}$ a form with late childhood regression, ${ }^{9}$ and a form with preservation of speech. ${ }^{10}$ Subsequently, it has been confirmed that MECP2 mutations are responsible for some of these variant forms. ${ }^{11-13}$

Given the various phenotypes that occur in relation to MECP2 mutations and the lack of a unified concept based on genotype/phenotype correlations, recent works have considered the problem of RTT through various approaches examining: prevalence and types of $M E C P 2$ mutations in girls with recognisable forms of RTT; genotype/phenotype correlations in patients with positive molecular findings ${ }^{14-16}$; and the search for MECP2 mutations in patients with mental disorders other than RTT, such as autism, ${ }^{17}$ and the occasional discovery of $M E C P 2$ mutations in relation to clinical pictures different from RTT, particularly in boys. ${ }^{18-22}$

In the present large series, we focused on an approach practical both for the clinician requesting MECP2 screening and for molecular geneticians: what is the likelihood of a positive test in phenotypes with decreasing clinical likelihood of RTT? To what extent are the criteria and scores proposed by RTT study groups helpful in predicting the presence of an

\section{Key points}

- MECP2 mutations have been described in typical cases of Rett syndrome (RTT) and in variant phenotypes. In this study we have retrospectively evaluated the likelihood of finding MECP2 mutation in phenotypes of decreasing concordance with a diagnosis of RTT.

- A cohort of 137 girls and 34 boys was studied. Three groups of girls were identified on the basis of positive necessary criteria as defined by the Rett Syndrome Diagnostic Criteria Work Group (RSDCWG) group: group 1, with "typical RTT" and exhibiting 6/6 positive necessary criteria, group 2 which were "atypical cases" with three to five such criteria, and group 3 with "poorly specific mental retardation" and with less than three criteria. An RT score as proposed by the Osaka group was calculated for each patient and evaluated as a tool to select candidates for MECP2 genotyping.

- Twenty five of 28 girls (89\%) from group 1, 24/55 (47\%) from group 2, and $3 / 58(5 \%)$ from group $3 \mathrm{had}$ mutated genes. RTT scores appeared to be poorly discriminant, as non-specific negative criteria, such as normal head circumference at birth, bear the same weight as positive criteria, such as loss of hand skills.

- Concurrence of the four following criteria: severe psychomotor retardation and impaired language, loss of purposeful hand skills, stereotypic hand movements, and acquired low head circumference, was highly predictive $(90 \%)$ of an MECP2 mutation independent of any anamnestic data. The likelihood of an MECP2 mutation can thus be evaluated adequately with a simplified RT score based on a restricted number of positive major criteria.

MECP2 mutation? Finally, which patients warrant additional screening beyond the $M E C P 2$ coding sequence to other types of mutations, whether in $M E C P 2$ non-coding sequence or in other genes?

Abbreviations: $C T D, C$-terminal domain; $M B D$, methyl binding domain; NLS, nuclear localisation signal; RTT, Rett syndrome; RSDCWG, Rett Syndrome Diagnostic Criteria Work Group; TRD, transcription repression domain 


\section{METHODS}

Population

This retrospective study studied a cohort of 171 patients (137 girls, 34 boys) from June 2000 to September 2002. We included patients for whom a search for an MECP2 mutation had been performed, with the exception of a few girls who had acquired perinatal brain lesions, progressive CNS disease, or the presence of a major malformation which was clear at the retrospective analysis. Fetal hypotrophy and microcephaly at birth were not a priori cause for exclusion.

$M E C P 2$ genotyping was requested through various medical channels: departments of paediatric neurology and paediatrics, both academic and non-academic; paediatricians working in institutions for children with developmental difficulties; and an association of families in which one child had been diagnosed with RTT.

\section{Clinical items}

Information was collected via questionnaire. In addition to general information, criteria of inclusion (necessary criteria), criteria of exclusion, and supportive criteria indicated in the literature (RTT Diagnostic Criteria Work Group 1988 ${ }^{23}$ (appendix A) were examined. Some questions were closed, others open. Though most physicians were informed of the $M E C P 2$ genotype before the inquiry, they were asked for their motivation in requesting the test, as well as to which of the three groups mentioned below they would have attributed their patient prior to the test. Open questions were also asked about clinical items revisited after the results of a positive molecular test and free comments were solicited.

\section{Grouping of girls with decreasing likelihood for RTT syndrome}

Three groups were defined in girls:

1) A group of "typical cases". Group 1 included girls with the six positive necessary criteria defined by the RSDCWG group ${ }^{24}$ (appendix A), regardless of possible necessary negative criteria (normotrophism and normal head circumference at birth) or minor supportive criteria.

2) A group of "atypical cases". Members of group 2 lacked at least one positive necessary criteria but had at least 3/6 positive necessary criteria and possibly other minor criteria supportive of RTT as defined by Hagberg et al ${ }^{24}$ (appendix A).

3) A group of girls with non-progressive, non-syndromic mental retardation, including the possibility of autistic features, who presented less than three RSDCWG positive necessary criteria.

In the three groups, no specific aetiology was identified by MRI or metabolic examination. For most patients, standard cytogenetic investigation was found to be normal prior to MECP2 genotyping or after a negative result. Some of the non-mutated patients were tested for common micro deletion syndromes by FISH, with negative results.

\section{Evaluation of a specific RTT score}

Each case was given a score reflecting the concordance of the phenotype with the typical RTT syndrome. From the several criteria proposed by Hagberg ${ }^{23}$, Inui $e a^{25}$ constructed a score that we used with a slight modification: we suppressed the item "diagnosis tentative until 2-5 years of age" according to the revision of RTT criteria suggested by Hagberg et al. ${ }^{23}$ However, as anamnesis was often unclear, we changed the item "apparently normal psychomotor development through the first 6 months" to "apparently regular psychomotor...". Each item receives a value of 1 and the maximum score is $8 / 8$.
The score is termed the "Osaka Modified Score" (OMS) $)^{25}$ (appendix B).

In boys MECP2 screening was considered for a cohort of patients with encephalopathy that met the following criteria: congenital, non-progressive encephalopathy with or without epilepsy; severe mental retardation; no evidence of specific cerebral lesion or disease by MRI, metabolic and infectiologic investigations; and normal standard karyotype. Most patients were also screened for FRAXA-FRAXE mutations. Besides general information, the questionnaire was directed toward dominant clinical symptoms and signs.

\section{Genotyping}

Genomic DNA was extracted from peripheral blood using standard methods. PCR amplification of exons 2, 3, and 4 was performed as described by Amir et $a l^{3}$ with the following modifications. Exon 4 was split into two fragments for PCR amplification. The primer 4.1 TTTGTCAGAGCGTTGTCACC localised within intron 3 was used with the reverse primer 4.4 CTGCACAGATCGGATAGAAGAC to amplify the $5^{\prime}$ portion of exon 4 . The $3^{\prime}$ portion of this exon 4 was amplified with the forward primer 4.3, AACCACCTAAGAAGCCCAAA and the reverse primer 4.10 CGGTAAGAAAAACATCCCCAA. The annealing temperatures were 58 and $60^{\circ} \mathrm{C}$, respectively. For some patients, exon 3 and the $5^{\prime}$ portion of exon 4 was amplified with one primer located within exon 3 AGCCCGTGCAGCCATCAGCC and primer 4.4. This amplification generated a fragment of 1539 nucleotides and was employed in response to a point mutation IVS3, $-89 \mathrm{C}>\mathrm{T}$ found in primer 3.1 sequence in one affected boy. The mutation inhibits PCR amplification of the MECP2 gene with primers 4.1 and 4.4; it was then tested for in 30 cases of Rett syndrome and not found. DNA sequencing was performed by using a BigDye dideoxy sequencing kit (Applied Biosystems) with the same primers or with the internal primers described by Amir et al. ${ }^{3}$ DNA sequences were analysed and compared to the reference sequence (GenBank, NM_004992) by using SeqScape V1.1. Mutations or deletions were considered as new when they were not referenced in the RettBASE (http:// MECP2.chw.edu.au).

\section{RESULTS}

\section{Girls}

Twenty-eight girls fell into group 1 (table 1), 25 of whom $(89 \%)$ were found to be have mutated genes, being affected by 15 different mutations or deletions (table 1). Three missense mutations involved the MBD. Two nonsense mutations were located within the NLS, one missense was located in another part of the TRD, and one missense mutation was located within the CTD. Five point or small deletions located within exon 4 led to a frameshift of the coding sequence in the CTD. One complex rearrangement located within exon 4 was not characterised.

Fifty one girls fell into group 2 (table 2), 27 of whom were found to not to have mutated genes (median age at test: 7 years), while $24(47 \%)$ had mutated genes (median age at test: 6 years), a proportion significantly lower than in group 1 $\left.\left(\chi^{2}, \mathrm{p}=0.0002\right)\right)$. Sixteen different mutations or deletions were found with five missense mutations involving the MBD. Three nonsense mutations were located within the TRD and two within the NLS. Four point or small deletions resulted in frameshift of the coding sequence within the TRD; two complex rearrangements were not characterised. One mutation substituted a guanine for an alanine (IVS3, $-2 A>G$ ) in the acceptor site of intron 3. A deletion of exon 2 and 3 was found in one patient.

In group 2, the OMS extended from 3 to 7 . The median score was 6 in both mutated (min-max $=5-7$ ) and nonmutated patients $(\min -\max =3-7)$. Eight cases exhibited 


\begin{tabular}{|c|c|c|c|c|c|}
\hline Patient & $\begin{array}{l}\text { Age of diagnosis } \\
\text { (years) }\end{array}$ & $\begin{array}{l}\text { Age of test } \\
\text { (years) }\end{array}$ & $\begin{array}{l}\text { OMS } \\
\text { score }\end{array}$ & $\begin{array}{l}\text { Nucleotide } \\
\text { change }\end{array}$ & $\begin{array}{l}\text { Amino acid } \\
\text { substitution }\end{array}$ \\
\hline 1 & 4 & 5 & 8 & 215 ins $C$ & Frameshift \\
\hline 2 & 2 & 20 & 8 & $397 C>T$ & Argl33Cys \\
\hline 3 & 3 & 36 & 8 & Idem & Idem \\
\hline 4 & 5 & 5 & 8 & Idem & Idem \\
\hline 5 & $\mathrm{Nd}$ & 10 & 8 & $403 A>G$ & Lys 135Glu \\
\hline 6 & 3 & 15 & 8 & $473 C>T$ & Thr158Met \\
\hline 7 & 4 & 11 & 8 & Idem & Idem \\
\hline 8 & $\mathrm{Nd}$ & 31 & 8 & Idem & Idem \\
\hline 9 & 3 & 3 & 8 & $502 C>T$ & $\operatorname{Arg} 168 X$ \\
\hline 10 & 4 & 8 & 8 & Idem & Idem \\
\hline 11 & 3 & 14 & 8 & $763 C>T$ & $\operatorname{Arg} 255 X$ \\
\hline 12 & $\mathrm{Nd}$ & 14 & 8 & $808 \mathrm{C}>\mathrm{T}$ & Arg270X \\
\hline 13 & 4 & 4 & 8 & Idem & Idem \\
\hline 14 & 3 & 22 & 8 & Idem & Idem \\
\hline 15 & 3 & 7.5 & 8 & $880 \mathrm{C}>\mathrm{T}$ & Arg270X \\
\hline 16 & $\mathrm{Nd}$ & 15 & 8 & $916 C>T$ & Arg306Cys \\
\hline 17 & 6,5 & 8 & 8 & Idem & Idem \\
\hline 18 & 3 & 3 & 8 & Idem & Idem \\
\hline 19 & 4 & 4 & 8 & $964 \mathrm{G}>\mathrm{C}$ & Pro322Ala \\
\hline 20 & $\mathrm{Nd}$ & nd & 8 & 1056 del 163 & Frameshift \\
\hline 21 & 2 & 27 & 8 & 1153 del 44 & Frameshift \\
\hline 22 & $\mathrm{Nd}$ & 21 & 8 & 1162 Del 30 & Frameshift \\
\hline 23 & 5 & 5 & 8 & 1160 del 21 & \\
\hline 24 & $\mathrm{Nd}$ & 15 & 8 & 1194 Ins T & \\
\hline 25 & 2 & 7 & 8 & Complex rearrangement & \\
\hline 26 & $\mathrm{Nd}$ & 9 & 8 & No mutation & \\
\hline 27 & 4 & 8.5 & 8 & No mutation & \\
\hline 28 & 4 & 10 & 8 & No mutation & \\
\hline
\end{tabular}

microcephaly at birth, four of whom had a mutation. Eight cases exhibited fetal hypotrophy, two of whom had a mutation.

Fifty five girls fell into group 3. Three $(6 \%)$ had mutated genes, significantly fewer than in group $2(\mathrm{p}<0.0001)$. Two were girls, 2 and 4 years old, respectively, and had psychomotor delay with poor speech development and autistic features. They had gait apraxia, but no RTT anamnestic profile, no deceleration of head growth, and no supportive criteria. The younger girl carried the highly prevalent $916 \mathrm{C}>\mathrm{T}$ missense mutation. The older child, who carried a 50 bp deletion starting in exon 4 , had various nonspecific stereotyped movements but purposeful hand skills were preserved. Her brother had slight mental retardation with behavioural difficulties, but without MECP2 mutation. The third girl, who carried a de novo missense mutation 909 C > G (Ile303Met), had an atypical phenotype: psychomotor acquisition was judged normal in infancy, and she first consulted at 3 years of age for an upper limb tremor. Examination at 12 years of age revealed a tremor of the "benign essential tremor" type with moderate handicap. She had slight mental retardation (IQ evaluated at 70, homogenous for verbal and performance abilities). Behaviour was dominated by striking shyness, with inhibition and blushing face and increasing diffuse vasomotor disturbances at each approach. Her mother had a slight, non-handicapping tremor.

The non-mutated girls of group 3 could be further separated into three subgroups:

- The first subgroup consisted of 29 girls with both mental retardation (IQ $<70$, among whom 10 cases were $<50$ ) and autistic traits. Nine girls had stereotypes including hand movements, but hand skills were in accordance with mental status. Twelve cases exhibited progressive microcephaly (normal head circumference at birth, but then between -2 and $-4 \mathrm{SD}$ ), while one patient had microcephaly at birth. In this subgroup, the OMS score was 5 or 6 in 17 girls and $<5$ in the remaining patients.
- The second subgroup consisted of 11 girls who had no specific mental retardation or clear autistic behaviour, but seven of whom had epilepsy. OMS score in this group was $<5$. Three cases had both microcephaly at birth and fetal hypotrophy.

- The third subgroup consisted of 15 girls with severe congenital encephalopathy (two familial and 13 sporadic). In five cases, clinical presentation was associated with cryptogenic infantile spasms. Presentation was severe infantile encephalopathy without recognisable etiology in the remaining 10 cases, five of whom exhibited progressive worsening epilepsy. Two cases in this group had microcephaly at birth and one also had fetal hypotrophy.

The median age at the test was 10 years (mean $(S D)=12.5(8.2)), 6$ years $($ mean $(S D)=7.3 \quad(5.2))$, and 5 years $($ mean $(S D)=6.2(4.8))$ in groups 1,2 and 3 , respectively (Kruskal-Wallis test, $\mathrm{p}=0.0006$ ). Compared with group 1, age was significantly lower in groups 2 $(\mathrm{p}=0.005)$ and $3(\mathrm{p}=0.0001)$.

Predictive value of restricted "necessary criteria" As our study did not aim at revisiting all the clinical criteria necessary to, or compatible with, a diagnosis of Rett syndrome, but rather at determining the best criteria for justifying a molecular test, we further analysed the predictive value of concurrence of different OMS items for mutation (predictive value indicates the proportion of patients with the criteria who had an MECP2 mutation). We observed that some criteria are less relevant than others and can be omitted without significant loss of prediction. Whereas concurrence of the eight OMS items had a predictive value of $89 \%$ (group 1), concurrence of the following four items, simplified from the OMS score, had a similar or even higher positive predictive value $(90.6 \%$, as all patients of group 1, and four mutated patients of group 2 corresponded to this profile): (1) apparent severe psychomotor retardation, severely impaired expressive and receptor language; (2) loss of acquired purposeful hand skills associated with communication 


\begin{tabular}{|c|c|c|c|c|c|c|}
\hline$n$ & $\begin{array}{l}\text { Age of diagnosis } \\
\text { (years) }\end{array}$ & $\begin{array}{l}\text { Age of test } \\
\text { (years) }\end{array}$ & $\begin{array}{l}\text { Missing necessary } \\
\text { criteria }\end{array}$ & $\begin{array}{l}\text { OMS } \\
\text { score }\end{array}$ & $\begin{array}{l}\text { Nucleotide } \\
\text { change }\end{array}$ & $\begin{array}{l}\text { Amino acio } \\
\text { substitution }\end{array}$ \\
\hline 1 & 2 & 6 & $5,7,8$ & 5 & $397 C>T$ & Arg133Cys \\
\hline 2 & 4 & 4 & 4 & 7 & Idem & Idem \\
\hline 3 & 2 & 6 & 4 & 7 & $422 A>G$ & Tyr141Cys \\
\hline 4 & 3 & 3 & 5 & 7 & $455 \mathrm{C}>\mathrm{T}$ & Prol52Arg \\
\hline 5 & 3 & 6 & 5 & 7 & $452 A>G$ & Asp151Gly \\
\hline 6 & $\mathrm{Nd}$ & 16 & 8 & 7 & $473 C>T$ & Thr1 58Met \\
\hline 7 & 5 & 5 & 6,8 & 6 & Idem & Idem \\
\hline 8 & 2 & 2 & 4,8 & 6 & Idem & Idem \\
\hline 9 & $\mathrm{Nd}$ & 14 & 5 & 5 & Idem & Idem \\
\hline 10 & 4 & 4 & 5,8 & 6 & Idem & Idem \\
\hline 11 & 2 & 10 & 8 & 6 & $502 C>T$ & Arg $168 X$ \\
\hline 12 & $\mathrm{Nd}$ & 11 & 4 & 7 & $763 C>T$ & Arg $255 X$ \\
\hline 13 & 5 & 5 & 5,8 & 6 & Idem & Idem \\
\hline 14 & 2 & 2 & 5,8 & 6 & Idem & Idem \\
\hline 15 & $\mathrm{Nd}$ & 9 & 8 & 6 & 807 del C & Frameshift \\
\hline 16 & $\mathrm{Nd}$ & 9 & 8 & 7 & $808 \mathrm{C}>\mathrm{T}$ & Arg270X \\
\hline 17 & 3 & 8 & 5,7 & 6 & $880 \mathrm{C}>\mathrm{T}$ & Arg294X \\
\hline 18 & 2 & 6 & 4 & 6 & $1156 \mathrm{Del} 41$ & Frameshift \\
\hline 19 & $\mathrm{Nd}$ & 14 & 4 & 7 & $1156 \mathrm{Del} 41$ & Frameshift \\
\hline 20 & 4 & 4 & 4 & 7 & $1157 \mathrm{Del} 32$ & Frameshift \\
\hline 21 & 2 & 6 & 4,5 & 6 & IVS $3,-2 A>G$ & Frameshift \\
\hline 22 & 3 & 3 & $4,7,8$ & 5 & $\begin{array}{l}\text { Complex } \\
\text { rearrangement }\end{array}$ & \\
\hline 23 & 3 & 3 & $4,5,8$ & 6 & $\begin{array}{l}\text { Complex } \\
\text { rearrangement }\end{array}$ & \\
\hline 24 & 2 & 2 & 5,8 & 6 & Del exons 2-3 & \\
\hline
\end{tabular}

dysfunction and social withdrawal; (3) stereotypic hand movements (wringing/squeezing/clapping/tapping, mouthing, and washing/rubbing automatisms); and (4) acquired low head circumference. Concurrence of other criteria had high, though less predictive values. Concurrence of the former criteria 1, 2, and 3 (the criterion "acquired low head circumference" being absent) had a predictive value of $64 \%$ that the patients would have mutated genes. The predictive value of having an MECP2 mutation dropped to $34 \%$ when the criterion "Acquired low head circumference" replaced "Stereotypic hand movements" (this latter criterion being absent). Only one mutated and two unmutated girls were reported with loss of hand skills without hand stereotypes The concurrence of a limited number of criteria with the exclusion of others, was either not encountered in the present population or had a low predictive value. For example, no girl had "loss of acquired purposeful hand skills associated with communication dysfunction and social withdrawal" without also having "apparent severe psychomotor retardation, severely impaired expressive and receptor language". Concurrence of the four following exclusive criteria: (1) "Apparently normal perinatal period", (2) "apparently regular psychomotor development through the first 6 months", (3) "normal head circumference at birth", and (4) "development of severely impaired expressive and receptor language, apparent severe psychomotor retardation" had a very low predictive value: only $3.7 \%$ patients from this group had an MECP2 mutation.

\section{Boys}

MECP2 screening was performed in 34 patients. A subgroup of 23 had non-specific, sporadic congenital encephalopathy with severe or profound mental retardation. Epilepsy was present in 16 (infantile spasms in two), inferior limb spasticity in 14, dystonic movements in seven, autistic traits including hand stereotypes in 13, and an episode of respiratory failure leading to death was present in one. Eleven other patients had non-specific mental retardation or borderline mental status (IQ between 50 and 79) with associated autistic features, three of them with stereotypic hand movements. Three cases were familial, two of them with a pedigree compatible with X-linked transmission. Neurological symptoms or signs (seizures, microcephaly, and moderate spasticity) were present in three. No patient was found to be mutated. One patient had a point mutation in intron 2.

\section{Motivation for MECP2 genotyping}

To determine the clinical criteria used by paediatricians requesting the biological test, the clearest result was that paediatric neurologists and geneticists fell into two different groups: the geneticists used selective criteria while the generalist paediatricians had a tendency to assume that mental retardation and autistic traits in a girl was compatible with Rett syndrome (data not shown).

\section{DISCUSSION}

\section{High frequency of mutations in typical cases}

When patients are selected according to strict clinical criteria, $^{24}$ the likelihood of finding a mutation in MECP2 coding sequences appears to be very high, nearly $90 \%$ in the present large series. Most series on RTT, in contrast, have reported a frequency of mutation usually lower and highly variable, between 35 and $77 \%$ of cases. ${ }^{15}{ }^{25-37}$ This difference is likely due to the fact that phenotypes were less strictly defined. Our results are more in accordance with other, less systematised studies where patients were grossly subdivided into "typical" or "classical" cases, reaching a positivity $>80 \%$, whereas "possible cases" or "retarded patients with Rett-like features" reached a positivity of $<50 \%{ }^{4}{ }^{38-40}$ In our series, median age when tested in typical cases was higher than that calculated in non-typical or non-specific cases. This result probably reflects the fact that the phenotype is more likely to be complete as the child grows up. The large reserve of old mostly typical patients waiting for MECP2 genotyping may also have increased the mean age of group 1. It remains to be determined whether this figure holds true for every ethnic group. We can only observe that various ethnic groups were represented in our cohort, as is generally the case in genetic studies in France. 


\begin{tabular}{|c|c|c|c|c|}
\hline Patients & $\begin{array}{l}\text { Age of tentative } \\
\text { diagnosis (years) }\end{array}$ & Age of test (years) & $\begin{array}{l}\text { Missing necessary } \\
\text { criteria }\end{array}$ & OMS score \\
\hline 1 & 1.5 & 1.5 & $4,5,7$ & 5 \\
\hline 2 & 2 & 7 & 4 & 7 \\
\hline 3 & $\mathrm{Nd}$ & 14 & 5 & 7 \\
\hline 4 & $\mathrm{Nd}$ & 10.5 & 5 & 7 \\
\hline 5 & 3.5 & 3.5 & $4,5,6$ & 3 \\
\hline 6 & 2.5 & 2.5 & 5,6 & 6 \\
\hline 7 & 3 & 9 & 5,8 & 6 \\
\hline 8 & 2 & 2 & 5 & 7 \\
\hline 9 & $\mathrm{Nd}$ & $\mathrm{Nd}$ & 5,8 & 6 \\
\hline 10 & $\mathrm{Nd}$ & 6.5 & 5,8 & 6 \\
\hline 11 & 6 & 11 & 4,5 & 6 \\
\hline 12 & 4.5 & 4.5 & 4,5 & 6 \\
\hline 13 & $\mathrm{Nd}$ & 16 & 5,8 & 6 \\
\hline 14 & 1.5 & 1.5 & $4,5,8$ & 4 \\
\hline 15 & $\mathrm{Nd}$ & 10 & 5 & 7 \\
\hline 16 & $\mathrm{Nd}$ & 9 & 5,8 & 6 \\
\hline 17 & 1.6 & 1.6 & 5,6 & 6 \\
\hline 18 & 2.5 & 2.5 & 6,8 & 5 \\
\hline 19 & 3 & 3 & 5,6 & 6 \\
\hline 20 & $\mathrm{Nd}$ & 22 & 4 & 7 \\
\hline 21 & 2 & 2 & $5,6,8$ & 5 \\
\hline 22 & $\mathrm{Nd}$ & $\mathrm{Nd}$ & 4,8 & 4 \\
\hline 23 & 4 & 11 & 5,8 & 4 \\
\hline 24 & $\mathrm{Nd}$ & 22 & 5,8 & 6 \\
\hline 25 & 2.5 & 2.5 & 5,7 & 5 \\
\hline 26 & 5 & 15 & 6,8 & 6 \\
\hline 27 & $\mathrm{Nd}$ & 10 & 4 & 5 \\
\hline
\end{tabular}

\section{Poor selectivity of scores in use}

Whereas the selection of well-defined clinical criteria helps in the search for MECP2 mutations, all individual criteria do not have the same weight. The most classical features, defined by Rett and revisited by Hagberg et al, ${ }^{1}$ do manifest a high specificity: the stagnation-regression of the psychomotor abilities after months of regular development, the reduction of purposeful hand movements, and the presence of monotonous hand stereotypes, when present, make the compilation of other diagnostic criteria unnecessary. In particular, the criterion "typical course in infancy" is often lacking, due to inaccurate anamnestic information. ${ }^{41}{ }^{42}$ Nevertheless, the present inquiry shows that the simple concurrence, in a young girl, of mental retardation, low head circumference, autistic traits, and striking anomalies of hand use implies the same likelihood for an MECP2 gene defect. Our inquiry suggests two other relevant points: (1) most practicians poorly differentiate "hand stereotypies" observed in RTT from other stereotypies observed in autistic children. This is not a serious drawback, as the hand stereotypies most characteristic of RTT are regularly associated with a loss of purposeful hand movements, the latter item being the easiest to observe; and (2) some "inclusion criteria" according to the RSDCW group, though undoubtedly relevant to RTT diagnosis, individually remain unspecific, such as "apparently normal perinatal period" or "normal head circumference at birth". Features such as early deviant communicative ability, delayed nociception, sudden laughing/screaming spells, spine deformation, and even cold impaired vasomotor regulation can also be encountered in a large array of severe cerebral and mental disorders of infancy.

All present considerations indicate that the Osaka score appears poorly discriminatory between mutated and nonmutated cases as shown in group 2, in which many patients with scores in the range of 4-7 could be mutated or nonmutated. Any score used in clinical practice requires separate analysis of the different items. The Osaka score would be more discriminatory if the classical, major abnormal criteria were weighted with a higher value. The present experience suggests that all patients combining at least three of the six necessary positive criteria (appendix A) should receive molecular screening, the less frequent criteria being "gait apraxia" and "communication dysfunction with loss of learned words" (table 2a). As regards research prospects, such as searching for mutations in non-coding MECP2 sequences or in other genes involved in gene transcription regulation through CpG-methylation, the priority would logically be to include cases combining all positive necessary criteria rather than those exhibiting undifferentiated elevated Osaka scores.

\section{Genotype/phenotype correlations}

In $M E C P 2$ disorders, correlation between specific mutations and phenotypes remains uncertain. In our series as in others, ${ }^{14} 16354043-45$ no clear phenotypic characteristics were observed when considering the effect of the mutation (missense, non-sense, deletion) or the expression of the most frequent mutations such as $379 \mathrm{C}>\mathrm{T}$, $397 \mathrm{C}>\mathrm{T}$, $473 \mathrm{C}>\mathrm{T}$, and $763 \mathrm{C}>\mathrm{T}$. Incomplete phenotypes, such as Rett syndrome with preservation of speech, appear to be linked to modifying factors rather than specific mutations. ${ }^{12}$ Whether the $\mathrm{X}$ inactivation profile significantly interferes with the phenotype remains unclear, ${ }^{14} 354647$ and was not studied in the present series. It should be mentioned that one missense mutation ( $909 \mathrm{C}>\mathrm{G}$, Ile303Met) not reported in international data bases was found in an atypical phenotype.

\section{Non-significant involvement of MECP2 in boys}

MECP2 mutations have been shown to be responsible for severe congenital encephalopathy in boys, especially in sibships including a girl with typical RTT syndrome..$^{21} 4849$ Though also possible in sporadic encephalopathies, ${ }^{19}$ our series suggests that MECP2 mutations do not represent a significant cause in this situation. As no suggestive clinical feature is capable of orienting the diagnosis, the search for MECP2 mutations in boys, in common practice, should be limited either to certain cases of familial X-linked mental 
retardation ${ }^{18} 22$ or to severe congenital encephalopathy in a family including an RTT girl.

Our study suggested that a large proportion of paediatricians continues to think that "MECP2 is highly mutated in $\mathrm{X}$-linked mental retardation", ${ }^{18}$ both in specific and nonspecific mental retardation, especially in girls. Whereas widespread MECP2 screening of mental retardation cases was certainly justified in the few years following the discovery of the gene, the present experience suggests that at least three positive necessary criteria are a reasonable prerequisite for the test in common practice. Regular information on the phenotypes related to MECP2 mutations, whether typical or less typical of RTT, will remain necessary in the near future.

\section{ACKNOWLEDGEMENTS}

We thank Isabelle Boucly for her technical help with DNA genotyping and KBB Sobering for her help with the editorial management of the manuscript.

\section{Authors' affiliations \\ F Kammoun, M Tardieu, P Landrieu, Service de Neurologie Pédiatrique CHU Bicêtre, 94275 Le Kremlin-Bicetre Cedex, France \\ $\mathrm{N}$ de Roux, Laboratoire d'Hormonologie et Biologie Moléculaire, $\mathrm{CHU}$ Bicêtre, 94275 Le Kremlin-Bicêtre, France \\ O Boespflug-Tanguy, Service de Neuropédiatrie, CHU de Clermont Ferrand, Hotel-Dieu, 63003 Clermont Ferrand Cedex 1, France \\ L Vallée, Service de Neuropédiatrie, CHRU de Lille, Hopital Roger Salengro, 59037 Lille Cedex, France \\ R Seng, Service d'épidémiologie et de santé publique, CHU Bicêtre, 94275 Le Kremlin-Bicêtre, France \\ Conflict of interest: none declared.}

Correspondence to: P Landrieu, Service de Neurologie Pédiatrique, CHU Bicêtre, 94275 Le Kremlin-Bicetre Cedex, France; pierre.landrieu@ bct.ap-hop-paris.fr

Received 14 November 2003

Accepted 17 November 2003

\section{APPENDIX A}

Diagnosis criteria according to the Rett Syndrome Diagnostic Criteria Work Group (RSDCWG) revised by Hagberg et al. ${ }^{23}$ In the present study, the six "positive necessary criteria" are numbers 2, 4, 5, 6, 7, and 8, and the two "negative necessary criteria" are numbers 1 and 3 .

\section{NECESSARY CRITERIA}

1. Apparently normal prenatal and perinatal history

2. Psychomotor development largely normal through the first 6 months or may be delayed from birth (in a girl with ultimate mental deficiency)

3. Normal head circumference at birth

4. Postnatal deceleration of head growth in the majority

5. Loss of achieved purposeful hand skills between ages 6 and 30 months

6. Stereotypic hand movements such as hand wringing/ squeezing, clapping/tapping, mouthing, and washing/ rubbing automatisms

7. Emerging social withdrawal, communication dysfunction, loss of learned words, and cognitive impairment

8. Impaired (dyspraxic) or failing locomotion

\section{SUPPORTIVE CRITERIA}

- Awake disturbances of breathing (hyperventilation, breath-holding, forced expulsion of air or saliva, air swallowing)
- Bruxism

- Impaired sleep pattern from early infancy

- Abnormal muscle tone successively associated with muscle wasting and dystonia

- Peripheral vasomotor disturbances

- Scoliosis/kyphosis progressing through childhood

- Growth retardation

- Hypotrophic small and cold feet; small, thin hands

\section{APPENDIX B. THE "OSAKA MODIFIED SCORE" EVALUATED IN THE PRESENT STUDY ${ }^{25}$ (EACH CRITERION HAS A VALUE OF 1)}

- Apparently normal perinatal period

- Apparently regular psychomotor development through the first 6 months

- Normal head circumference at birth

- Deceleration of head growth between the ages of 5 months and 6 years

- Loss of acquired purposeful hand skills between the ages of 6 months and 30 months, associated with communication dysfunction and social withdrawal

- Development of severely impaired expressive and receptor language, presence of apparent severe psychomotor retardation

- Stereotypic hand movements such as hand wringing/ squeezing/clapping/tapping, mouthing, and washing/rubbing automatisms appearing after hand skills are lost

- Appearance of gait apraxia and truncal apraxia/ataxia between the ages of 1 and 4 years.

\section{REFERENCES}

1 Hagberg B, Aicardi J, Dias K, Ramos O. A progressive syndrome of autism, dementia, ataxia, and loss of purposeful hand use in girls: Rett's syndrome: report of 35 cases. Ann Neurol 1983;14:471-9.

2 Hagberg B, Goutieres F, Hanefeld F, Rett A, Wilson J. Rett syndrome: criteria for inclusion and exclusion. Brain Dev 1985;7:372-3

3 Amir RE, Van den Veyver IB, Wan M, Tran CQ, Francke U, Zoghbi HY. Rett syndrome is caused by mutations in X-linked MECP2, encoding methyl-CpGbinding protein 2. Nat Genet 1999;23:185-8.

4 Auranen M, Vanhala R, Vosman M, Levander M, Varilo T, Hietala M, Riikonen R, Peltonen L, Jarvela I. MECP2 gene analysis in classical Reft syndrome and in patients with Rett-like features. Neurology 2001;56:611-7.

5 Nomura $Y$, Segawa $M$, Higurashi $M$. Rett syndrome - an early catecholamine and indolamine deficient disorder? Brain Dev 1985;7:334-41.

6 Rolando S. Rett syndrome: report of eight cases. Brain Dev 1985;7:290-6.

7 Hanefeld F. The clinical pattern of the Rett syndrome. Brain Dev 1985;7:320-5

8 Hagberg B, Rasmussen P. "Forme fruste" of Rett syndrome-a case report. Am J Med Genet 1986; 1(suppl):175-81

9 Gillberg C. The borderland of autism and Rett syndrome: five case histories to highlight diagnostic difficulties. J Autism Dev Disord 1989;19:545-59.

10 Zappella M, Meloni I, Longo I, Canitano R, Hayek G, Rosaia L, Mari F, Renieri A. Study of MECP2 gene in Rett syndrome variants and autistic girls. Am J Med Genet 2003;119(B): 102-7

11 De Bona C, Zappella M, Hayek G, Meloni I, Vitelli F, Bruttini M, Cusano R, Loffredo P, Longo I, Renieri A. Preserved speech variant is allelic of classic Rett syndrome. Eur J Hum Genet 2000:8:325-30.

12 Yamashita Y, Kondo I, Fukuda T, Morishima R, Kusaga A, Iwanaga R, Matsuishi T. Mutation analysis of the methyl-CpG-binding protein 2 gene (MECP2) in Rett patients with preserved speech. Brain Dev 2001;23:S157-60.

13 Heilstedt HA, Shahbazian MD, Lee B. Infantile hypotonia as a presentation of Rett syndrome. Am J Med Genet 2002;111:238-42.

14 Amir RE, Zoghbi HY. Rett syndrome: methyl-CpG-binding protein 2 mutations and phenotype-genotype correlations. Am J Med Genet 2000;97:147-52.

15 Huppke P, Laccone F, Kramer N, Engel W, Hanefeld F. Rett syndrome: analysis of MECP2 and clinical characterization of 31 patients. Hum Mol Genet 2000;9:1369-75

16 Huppke P, Held M, Hanefeld F, Engel W, Laccone F. Influence of mutation type and location on phenotype in 123 patients with Rett syndrome. Neuropediatrics 2002;33:63-8.

17 Vourc'h P, Bienvenu T, Beldjord C, Chelly J, Barthelemy C, Muh JP, Andres C. No mutations in the coding region of the Rett syndrome gene MECP2 in 59 autistic patients. Eur J Hum Genet 2001;9:556-8. 
18 Couvert P, Bienvenu T, Aquaviva C, Poirier K, Moraine C, Gendrot C, Verloes A, Andres C, Le Fevre AC, Souville I, Steffann J, des Portes V, Ropers HH, Yntema HG, Fryns JP, Briault S, Chelly J, Cherif B. MECP2 is highly mutated in X-linked mental retardation. Hum Mol Genet 2001; 10:941-6.

19 Imessaoudene B, Bonnefont JP, Royer G, Cormier-Daire V, Lyonnet S, Lyon G, Munnich A, Amiel J. MECP2 mutation in non-fatal, non-progressive encephalopathy in a male. J Med Genet 2001;38:171-4.

20 Meloni I, Bruttini M, Longo I, Mari F, Rizzolio F, D'Adamo P, Denvriendt K, Fryns JP, Toniolo D, Renieri A. A mutation in the Rett syndrome gene, MECP2, causes $X$-linked mental retardation and progressive spasticity in males. Am J Hum Genet 2000;67:982-5.

21 Geerdink N, Rotteveel JJ, Lammens M, Sistermans EA, Heikens GT, Gabreels FJ, Mullaart RA, Hamel BC. MECP2 mutation in a boy with severe neonatal encephalopathy: clinical, neuropathological and molecular findings Neuropediatrics 2002;33:33-6.

22 Dotti MT, Orrico A, De Stefano N, Battisti C, Sicurelli F, Severi S, Lam CW, Galli L, Sorrentino V, Federico A. A Rett syndrome MECP2 mutation that causes mental retardation in men. Neurology 2002;58:226-30.

23 Hagberg B, Hanefeld F, Percy A, Skjeldal O. An update on clinically applicable diagnostic criteria in Rett syndrome. Comments to Rett Syndrome Clinical Criteria Consensus Panel Satellite to European Paediatric Neurology Society Meeting, Baden Baden, Germany, 11 September 2001. Eur J Paediatr Neurol 2002;6:293-7.

24 Hagberg G, Stenbom Y, Engerstrom IW. Head growth in Rett syndrome. Brain Dev $2001 ; 23:$ S227-9

25 Invi K, Akagi M, Ono J, Tsukamoto H, Shimono K, Mano T, Imai K, Yamada M, Muramatsu T, Sakai N, Okada S. Mutational analysis of MECP2 in Japanese patients with atypical Rett syndrome. Brain Dev 2001 23:212-5.

26 Amano K, Nomura Y, Segawa M, Yamakawa K. Mutational analysis of the MECP2 gene in Japanese patients with Rett syndrome. J Hum Genet 2000;45:231-6

27 Bienvenu T, Carrie A, de Roux N, Vinet MC, Jonveaux P, Couvert P, Villard L, Arzimanoglou A, Beldjord C, Fontes M, Tardieu M, Chelly J. MECP2 mutations account for most cases of typical forms of Rett syndrome. Hum Mol Genet 2000;9:1377-84

28 Gill H, Cheadle JP, Maynard J, Fleming N, Whatley S, Cranston T, Thompson EM, Leonard H, Davis M, Christodoulou J, Skjeldal O, Hanefeld F, Kerr A, Tandy A, Ravine D, Clarke A. Mutation analysis in the MECP2 gene and genetic counselling for Rett syndrome. J Med Genet 2003;40:380-4.

29 Hampson K, Woods CG, Latif F, Webb T. Mutations in the MECP2 gene in a cohort of girls with Rett syndrome. J Med Genet 2000;37:610-2.

30 Hoffbuhr K, Devaney JM, LaFleur B, Sirianni N, Scacheri C, Giron J, Schuette J, Innis J, Marino M, Philippart M, Narayanan V, Umansky R, Kronn D, Hoffman EP, Naidu S. MeCP2 mutations in children with and without the phenotype of Rett syndrome. Neurology 2001;56:1486-95.

31 Chae JH, Hwang YS, Kim KJ. Mutation analysis of MECP2 and clinical characterization in Korean patients with Rett syndrome. J Child Neurol 2002;17:33-6.

32 Conforti FL, Mazzei R, Magariello A, Patitucci A, Gabriele AL, Muglia M, Quattrone A, Fiumara A, Barone R, Pavone L, Nistico R, Mangone L. Mutation analysis of the MECP2 gene in patients with Rett syndrome. Am J Med Genet 2003;117A:184-7.

33 Monros E, Armstrong J, Aibar E, Poo P, Canos I, Pineda M. Rett syndrome in Spain: mutation analysis and clinical correlations. Brain Dev 2001;23:S251-3

34 Nicolao P, Carella M, Giometto B, Tavolato B, Cattin R, GiovannucciUzielli ML, Vacca M, Regione FD, Piva S, Bortoluzzi S, Gasparini P. DHPLC analysis of the MECP2 gene in Italian Rett patients. Hum Mutat 2001; 18:132-40.

35 Nielsen JB, Henriksen KF, Hansen C, Silahtaroglu A, Schwartz M, Tommerup N. MECP2 mutations in Danish patients with Rett syndrome: high frequency of mutations but no consistent correlations with clinical severity or with the X chromosome inactivation pattern. Eur J Hum Genet $2001 ; 9: 178-84$

36 Pan H, Wang YP, Bao XH, Meng HD, Zhang Y, Wu XR, Shen Y. MECP2 gene mutation analysis in Chinese patients with Rett syndrome. Eur J Hum Genet 2002; 10:484-6

37 Vacca M, Filippini F, Budillon A, Rossi V, Mercadante G, Manzati E, Gualandi F, Bigoni S, Trabanelli C, Pini G, Calzolari E, Ferlini A, Meloni I, Hayek G, Zappella M, Renieri A, D'Urso M, D'Esposito M, MacDonald F, Kerr A, Dhanjal S, Hulten M. Mutation analysis of the MECP2 gene in British and Italian Rett syndrome females. J Mol Med 2001;78:648-55.

38 Buyse IM, Fang P, Hoon KT, Amir RE, Zoghbi HY, Roa BB. Diagnostic testing for Rett syndrome by DHPLC and direct sequencing analysis of the MECP2 gene: identification of several novel mutations and polymorphisms. Am J Hum Genet 2000;67:1428-36.

39 Erlandson A, Hallberg B, Hagberg B, Wahlstrom J, Martinsson T. MECP2 mutation screening in Swedish classical Rett syndrome females. Eur Child Adolesc Psychiatry 2001;10:117-21.

40 Yamada Y, Miura K, Kumagai T, Hayakawa C, Miyazaki S, Matsumoto A, Kurosawa K, Nomura N, Taniguchi H, Sonta SI, Yamanaka T, Wakamatsu N. Molecular analysis of Japanese patients with Rett syndrome: identification of five novel mutations and genotype-phenotype correlation. Hum Mutat $2001 ; 18: 253$.

41 Charman T, Cass H, Owen L, Wigram T, Slonims V, Weeks L, Wisbeach A Reilly S. Regression in individuals with Rett syndrome. Brain Dev 2002;24:281-3

42 Fiumara A, Barone R, D'Asero G, Marzullo E, Pavone L. Rett syndrome: photographic evidence of rapid regression. J Child Neurol 1999;14:550-2.

43 Shahbazian MD, Zoghbi HY. Molecular genetics of Rett syndrome and clinical spectrum of MECP2 mutations. Curr Opin Neurol 2001;14:171-6.

44 Giunti L, Pelagatti S, Lazzerini V, Guarducci S, Lapi E, Coviello S, Cecconi A Ombroni L, Andreucci E, Sani I, Brusaferri A, Lasagni A, Ricotti G, Giometto B Nicolao P, Gasparini P, Granatiero M, Uzielli ML. Spectrum and distribution of MECP2 mutations in 64 Italian Rett syndrome girls: tentative genotype/ phenotype correlation. Brain Dev 2001;23:S242-5.

45 Weaving LS, Williamson SL, Bennetts B, Davis M, Ellaway CJ, Leonard H, Thong MK, Delatycki M, Thompson EM, Laing N, Christodoulou J. Effects of MECP2 mutation type, location and X-inactivation in modulating Rett syndrome phenotype. Am J Med Genet 2003;118A:103-14.

46 Takagi $\mathrm{N}$. The role of X-chromosome inactivation in the manifestation of Rett syndrome. Brain Dev 2001;23:S182-5.

47 Villard L, Levy N, Xiang F, Kpebe A, Labelle V, Chevillard C, Zhang Z, Schwartz CE, Tardieu M. Chelly J, Anvret M. Fontes M. Segregation of a totally skewed pattern of $X$ chromosome inactivation in four familial cases of Rett syndrome without MECP2 mutation: implications for the disease. J Med Genet 2001;38:435-42.

48 Zeev BB, Yaron Y, Schanen NC, Wolf H, Brandt N, Ginot N, Shomrat R, OrrUrtreger A. Rett syndrome: clinical manifestations in males with MECP2 mutations. J Child Neurol 2002;17:20-4.

49 Moog U, Smeets EE, van Roozendaal KE, Schoenmakers S, Herbergs J, Schoonbrood-Lenssen AM, Schrander-Stumpel CT. Neurodevelopmental disorders in males related to the gene causing Rett syndrome in females (MECP2). Eur J Paediatr Neurol 2003;7:5-12. 